\title{
İLİTAM Bölümü Öğrencilerinin Hadis Dersine Yönelik Tutumları
}

\begin{abstract}
Öz: Mezun ettiği öğrenci sayısı ve kontenjan dikkate alındığında 2005-2006 öğretim yılında eğitim hayatına başlayan İLİTAM bölümlerinde verilen eğitimin niteliği tartışılır hale gelmiştir. Bu tartışmaların ışığında yapılan akademik çalışmalar İLITAM programı ve öğrencilerine yönelik genel araştırma sonuçlarını içermekte fakat spesifik olarak ders bazında örgün eğitimle aralarındaki farkı incelememektedir. Bu bakımdan İlahiyat Fakültelerini örgün olarak okuyanlarla İlahiyat Lisans Tamamlama Programından mezun olanlar arasında nitelik açısında fark olup olmadığının ortaya konarak İLİTAM programlarının niteliği ve niceliği hakkında sağlıklı yorum yapılması sağlanmalıdır. Çalışmada bu amaca yönelik olarak İLİTAM öğrencilerinin hadis birikimi, hadis derslerine olan ilgileri ve bu derslerinden beklentileri araştırılmıştır. Araştırmada nicel desen üzerine kurgulanmış ve betimsel araştırma yöntemlerinden tarama modeli uygulanmıştır. Araştırmaya 2020-2021 öğretim yılında Kocaeli Üniversitesi İlâhiyat Fakültesi İLİTAM bölümü son sınıfta öğrenim gören 247 öğrenci katılmıştır. Araştırmada İLITAM programındaki hadis derslerinin sayısının yetersiz olduğu, İlahiyat ön lisansta okudukları Hadis Tarihi ve Usulü kaynaklarının yetersiz kaldığı, kendilerini örgün İlahiyat öğrencilerine göre yetersiz hissettikleri, İLİTAM programında yer alan Hadis Metinleri Dersinde hocaların usul konularına girmelerini önemsedikleri, Hadis Edebiyatından yararlanma konularında yetersiz kaldıkları, Hadis Tarihi ve Usulü konularında ders kitabı haricinde okuma yapmadıkları, Arapça eğitimi eksikliklerinden dolayı Hadis Metinleri Derslerinde zorlandıkları sonucu çıkmıştır.
\end{abstract}

Anahtar Kelimeler: İlahiyat, Eğitim, Uzaktan Eğitim, İLİTAM, Hadis.

\section{Muhammet Fatih GENC *}

Mehmet AYHAN

\section{Attitude of Students of the Department of Theology Undergraduate Completion Program (ILITAM) Towards Hadith Course}

Abstract: Considering the number of students graduated and the quota, the quality of the education given in the departments of ILITAM, which started its education life in the 2005-2006 academic year, has become controversial. Academic studies conducted in the light of these discussions include general research results for the ILITAM program and its students, but do not specifically examine the difference between them and formal education on a course basis. In this respect, it should be determined whether there is a difference in terms of quality between those who formally study at the Faculties of Theology and those who graduate from the Theology Undergraduate Completion Program, and it should be ensured that a healthy interpretation is made about the quality and quantity of ILITAM programs. In this context, in this study, the knowledge of ILITAM students, their interest in hadith lessons and their expectations from these lessons were investigated. The research was built on quantitative design and scanning model, which is one of the descriptive research methods, was applied. In the 2020-2021 academic year, 247 students studying in the last year of Kocaeli University Faculty of Theology, ILITAM department participated in the research. In the research, the number of hadith courses in the ILITAM program was insufficient, the hadith history and traditional sources they studied in theology associate degree were insufficient, they felt inadequate compared to the formal theology students, the teachers in the Hadith Texts course in the ILITAM program gave importance to the topics of procedure, they were insufficient in benefiting from the hadith literature. It was concluded that they did not read except for the course book in the subjects of Method and History, and that they had difficulty in hadith texts lessons due to their lack of Arabic education.

Keywords: Theology, Education, Distance Education, ILITAM, Hadith. 


\section{Giriş}

Uzaktan eğitim, öğretmen ve öğrencinin zamansal ve mekânsal olarak birbirinden farklı yerlerde olduğu alternatif bir eğitim modelidir.' Uzaktan eğitimde örgün eğitimden farklı olarak öğretmen ve öğrenci fiziksel olarak aynı mekânda değildir. Örgün eğitimde olduğu gibi yüz yüze iletişim yerine teknolojiden faydalanılır. ${ }^{2}$ Öğretmen ve öğrencinin fiziksel olarak birbirinden uzakta olması ilk bakışta bir dezavantaj gibi görünse de bu model sayesinde eğitimin paydaşları olan öğreten ve öğrenenlere zaman ve mekân esnekliği sağlanmaktadır. Bu durumda öğrenmeyi hedefleyen her bireyin eğitime ulaşmasında fırsat eşitliği sağladığı düşünülmektedir. ${ }^{3}$

Temeli yaklaşık iki yüz yıl öncesine dayanan uzaktan eğitim ülkemizdeki tarihi 1950 'li yıllara kadar gitmekle birlikte eğitim sisteminin günün koşullarına uygun bir şekilde değişmesi ve gelişmesine paralel olarak bu işe önem verilmesi 1974 tarihinden sonra olmuş ve daha sonraki yıllarda gelişerek yaygınlaşmıştır ${ }^{4}$ Bu gelişmelerin sonucunda ülkemizde farklı bölümleri içinde barındıran açık öğretim fakülteleri açılmıştır. Bu fakültelere bağlı olarak açılan bölümlerden biri de İlâhiyat Lisans Tamamlama Programı (ILITAM) programlarıdır. Türkiye'de ilk defa Ankara Üniversitesi'nde 2005-2006 öğretim yılında eğitime başlayan daha sonra 16 Illâhiyat Fakültesine yayılan ILITAM programından ${ }^{5}$ bugüne kadar 30 bin kişi yararlanmıştır. ${ }^{6}$

Günümüzde İlahiyat eğitiminin bir parçası olarak açılan İLiTAM programı başlangıçta Diyanet İşleri Başkanlığı (DiB) Personelinin niteliğini artırmak üzere düşünülmüştür. Ancak zaman içerisinde DiB personeli haricinde Illahiyat Meslek Yüksek Okulu Mezunlarının tamamını içine alacak şekilde kapsamı genişletilmiştir.

1 A.A. Gujjar ve M.A. Malik, "Preparation of instructional material for distance teacher education”, Turkish Online Journal of Distance Education, 8/1 (2007): 55-57.

2 M.G. Moore, "Theory of transactional distance." Theoretical principles of distance education içinde (London: Routledge, 1993). 22-26.

3 E. Bunker, "The history of distance education through the eyes of the international council for distance education", Handbook of distance education içinde ed. M. G. Moore ve W. G. Anderson, (New Jersey, Lawrence Erlbaum Associates, 2003), 50-52. Ders Videoları Aracılığıyla İncelenmesi”, (Yüksek Lisans Tezi Ondokuz Mayıs Üniversitesi, 2020), 10.

5 Tuncay Karateke, "ILITAM Öğrencilerinin Bu Programı Seçme Nedenleri ve Karşılaştıkları Sorunlar: Fırat Üniversitesi Örneği”, Değerler Eğitimi Dergisi 18/39 (Haziran 2020): 238.

6 Süleyman Gümrükçüoğlu ve Muhammet Fatih Genç, "ILiTAM Bölümü Öğrencilerinin Illâhiyat Eğitimine Bakışı Kocaeli Üniversitesi İlâhiyat Fakültesi İLiTAM Örneği", iHYA Uluslararası İslam Araştırmaları Dergisi, 6/2 (2020): 645. 
Nitekim 2018 yılında Yükseköğretim Kanunu'na eklenen geçici madde ile"ilahiyat ön-lisans programından mezun olanlara ilahiyat ve aynı programı uygulayan fakültelerde, eşdeğer alanlarda lisans tamamlama eğitimi yaptırılmasını; bu eğitimin usul ve esasları ile her yıl tahsis edilecek kontenjanlarının Yükseköğretim Kurulu tarafından belirlenmesini" ${ }^{\prime \prime}$ kararlaştırmıştır. Gerekçesi ise; "Illahiyat ön-lisans mezunlarının, bilimsel seviyelerinin yükseltilerek bu sayede topluma hizmet sorumluluklarının daha üst düzeyde yerine getirilmesi ve kamuda çalışanlarının özlük haklarının iyileştirilmesi" olarak belirtilmiştir. ${ }^{8}$ Bu tasarıya ek olarak kamuoyunda ILITAM programının açılma nedenleri arasında 28 Şubat mağduriyetini gidermek, Yüksek din öğrenimi gören kişi sayısını çoğaltmak, Diyanet İşler Başkanlığı́nda görev yapan din görevlilerinin eğitim düzeyini yükseltmek gibi nedenler de sayılmaktadır. ${ }^{9}$

İlgili kanunun çıkarılma gerekçesi olan insan kaynağı kalitesinin geliştirilmesi hedefi önemli olmakla birlikte ILITAM programlarının bu hedefleri ne kadar gerçekleştirebildiği ve nitelik boyutu illahiyat camiasında tartışmaların merkezi haline gelmiştir. Bu tartışmaların gölgesinde ILITAM ders programlan 2011- 2012 eğitim yılında illâhiyat ön lisans programları ile uyumlu hale getirilmiştir (YÖK, 2010/3044). Bu düzenleme ile ILITAM programlarında dört yarıyılda \% 65'i Temel İslam Bilimleri (Kur'an, Arapça, Sistematik Kelam, Fıkıh Usulü, İslam Hukuku, Hadis Metinleri, Tasavvuf, Tefsir vb.), \%25'i Felsefe ve Din Bilimleri (Felsefe Tarihi, İslam Felsefesi, İslam Ahlak Felsefesi, Din Felsefesi, Mantık, Dinler Tarihi), \%8'i İslam Tarihi ve \%2'si de Osmanlı Türkçesi dersi toplamda 80 kredi ders yer almaktadır. ${ }^{10}$ Yapılan bu düzenlemelere karşın ILITAM programında örgün Illâhiyat eğitimine kıyasla Arapça hazırlık sınıfının bulunmaması, örgün İlahiyat müfredatına göre sınırlı dersler ve yüzeysel içerikle sunulması ve çoktan seçmeli testlerle başarının ölçülmesi örgün Illahiyat eğitimine göre dezavantaj oluşturmaktadır. Bu durum https://www.mevzuat.gov.tr/MevzuatMetin/1.5.2547.pdf, Erişim Tarihi:22.05.2021. Atilla Arkan, "ilahiyat Eğitimi ve Illahiyat Lisans Tamamlama Programları (ILITAM)", Erişim Tarihi:23.02.2021, SETA, 28 Aralık 2018, https://www.setav.org/ilahiyat-egitimi-ve-ilahiyat-lisans-tamamlama-programlari-iLiTAM/.

9 Değerler Eğitimi Merkezi (DEM), "ilahiyat Lisans Tamamlama Programları ile Illgili Geçici Kanun Tasarısı Üzerine Değerlendirme" (2018), (Erişim Tarihi 17.04.2021).1-2.

10 Recep Kaymakcan,-Hasan Meydan ve Adnan Telli, "Paydaşlarına Göre Illahiyat Lisans Tamamlama (ILITAM) Programının Değerlendirilmesi", Değerler Eğitimi Dergisi = Journal of Values Education XI, 26 (2013): 97, Tuncay Karateke, "ILITAM Öğrencilerinin Bu Programı Seçme Nedenleri ve Karşılaştıkları Sorunlar: Fırat Üniversitesi Örneği", Değerler Eğitimi Dergisi 18/39 (Haziran 2020): 239. 
İLITAM programının tarihten günümüze Illahiyat eğitiminin genel karakteristiğini yansıtmadığına yönelik eleştirileri de beraberinde getirmektedir." Bu bağlamda 25. ve 26. Ilahiyat ve İslami İlimler Dekanlar Toplantısı Sonuç Bildirgesinde ILITAM Programı diğer bazı olumsuz yönlerinin yanında özellikle lllahiyat eğitim-öğretiminde kaliteyi olumsuz yönde etkileyen önemli faktörlerden biri olarak eleştirilmiş ve adalete aykırı olma, fırsat eşitsizliği vb. gerekçelerle programın kapatılması teklif edilmiştir. ${ }^{12}$ ILITAM programı ile ilgili yapılan akademik çalışmalar da bu eleştirileri haklı çıkarmaktadır. Yapılan araştırmalarda bu bölümde okuyan öğrencilerin öğretim elemanlarının uzaktan eğitim yeterliliklerini yeterli bulmadıkları, bu programda öğrenim görmekten tatmin olmadıkları, kendilerini örgün Illahiyat mezunlarına göre yetersiz gördükleri, yüz yüze eğitim imkânı olsa örgün İlahiyat eğitimini tercih edecekleri, öğrencilerinin uzaktan öğretime yönelik tutum düzeylerinin yüksek olmadığı ve programın ilahiyat eğitiminin kalitesini olumsuz etkilediği gerekçesiyle kapatılması gerektiği gibi sonuçlara ulaşıımıştır. ${ }^{13}$ Bu çalışmalar ILITAM programı ve öğrencilerine yönelik genel araştırma sonuçlarını içermekte fakat spesifik olarak ders bazında örgün eğitimle aralarındaki farkı incelememektedir. Bu bakımdan Illahiyat Fakültelerini örgün olarak okuyanlarla Illahiyat Lisans Tamamlama Programından mezun olanlar arasında nitelik açısından fark olup olmadığı ortaya konarak ILITAM programlarının niteliği ve niceliği hakkında sağlıklı yorum yapılması sağlanmalıdır. ${ }^{14}$

12 Bk. "25. İlâhiyat ve İslâmî Illimler Fakülteleri Dekanlar Toplantısı Sonuç Bildirgesi - İlahiyat Fakültesi", 226, erişim: 24 Nisan 2021, https://ilahiyat.sinop.edu.tr/25-ilahiyat-ve-islami-ilimler-fakulteleri-dekanlar-toplantisi-sonuc-bildirgesi/; "26. İlahiyat ve İslami Ilimler Dekanlar Toplantısı Sonuç Bildirisi", adanapost, erişim: 24 Nisan 2021, https://www.adanapost.com/26-ilahiyat-ve-islami-ilimler-dekanlar-toplantisi-sonuc-bildirisi-139717h.htm.

13 Bk. Yasemin Kılıç, Eş zamanlı ve eş zamansız uzaktan eğitim ortamlarındaki çevrimiçi etkileşimlerin yapısal çözümlemesi (Yüksek lisans tezi, Ankara Üniversitesi 2010); Recep Kaymakcan,-Hasan Meydan ve Adnan Telli, “Paydaşlarına Göre Illahiyat Lisans Tamamlama (ILITAM) Programının Değerlendirilmesi", Değerler Eğitimi Dergisi = Journal of Values Education XI, 26 (2013):71-110; Recep Kaymakcan, Hasan Meydan, Adnan Telli ve Yasemin Cevherli, "ilahiyat Lisans Tamamlama Programının Verimliliği Üzerine Olgusal Bir Araştırma", Hitit Üniversitesi Illahiyat Fakültesi Dergisi, 13/26 (2014), 43-62.; Nurullah Altaş, N. (2016). “Türkiye'de Dini Yükseköğretim Alanında Uzaktan Eğitimle Ilgili Algı Sorunları ve ILITAM Uygulamaları", Değerler Eğitimi Dergisi, 14/31 (2016):7-42; Fatma Arslan ve Özgen Korkmaz, (2019). "LiTAM Lisans Tamamlama Uzaktan Eğitim Öğrencilerinin Etkileşim Kaygıları ve Uzaktan Eğitime Dönük Tutumları", Ahmet Keleşoğlu Eğitim Fakültesi Dergisi, 1/1(2019): 12-25. Mustafa Köylü, (2013). "Türkiye'de Yüksek Din Öğretimi: Nicelik Mi Nitelik Mi?", Ondokuz Mayıs Üniversitesi Illahiyat Fakültesi Dergisi, 35/35 (2013): 21-44.

14 ILITAM programında ders veren öğretim elemanları ve öğrencilerinin programın fonksiyonn larına ve uygulama süreçlerinin kalitesine yönelik algılarıyla ilgili bir çalışma için bk. Recep 
Bu amacı ders bazında yerine getirmeyi hedefleyen çalışmamız Hadis Dersleri özelindedir. Bilindiği üzere İLITAM programında Hadis Metinleri I ve Hadis Metinleri II dersleri yer almaktadır. Hadis Tarihi ve Hadis Usulü Dersleri İlahiyat Ön Lisans programında yer almaktadır. Örgün İlahiyat eğitiminde ise 2015 yılından yapılan değişiklikle; ${ }^{15}$ ilk üç sınıfın tüm dönemlerine haftada ikişer saat olmak üzere toplam on iki saat "Hadis" dersine yer verilmiştir. Bu dersler birinci sınıfta "Hadis Tarihi ve Usulü" ikinci ve üçüncü sınıflarda "Hadis I", "Hadis II", "Hadis III" ve "Hadis IV" adıyla programda yer bulmuştur. ${ }^{16}$

Bu bağlamda çalışmada ILITAM öğrencilerinin hadis birikimi, hadis derslerine olan ilgileri ve bu derslerinden beklentileri araştırılmıştır. Elde edilen veriler örgün eğitimdeki hadis eğitimi hakkında yapılan araştırma sonuçlarıyla karşılaştırılarak analiz edilmiş ve öneriler sunulmuştur.

\section{Yöntem}

\subsection{Desen}

ILITAM bölümü öğrencilerinin hadis dersine yönelik tutumları hakkında bilgi vermeyi amaçlayan bu araştırma nicel desen üzerine kurgulanmış ve betimsel araştırma yöntemlerinden tarama modeli uygulanmıştır. Tarama modeli, çok sayıda bireyden oluşan bir evrende, evrenin tümü veya onu temsil eden örneklem üzerinden evrenin tümü hakkında genel bir yargıya varmak için yapılan tarama düzenlemeleridir. ${ }^{17}$

\section{2. Çalışma Grubu}

Araştırmanın evreni 2020-2021 öğretim yılında Kocaeli Üniversitesi Illâhiyat Fakültesi ILITAM bölümü son sınıfta öğrenim gören 911 öğrencidir. Araştırmanın örneklemi ise seçkisiz örnekleme yöntemiyle seçilen 247 öğrencinden oluşmaktadır.

Kaymakcan vd, “Paydaşlarına Göre Illahiyat Lisans Tamamlama (ILITAM) Programının Değerlendirilmesi"71-110.

Bk. Yüksek Öğretim Kurulu'nun 25.07.2015 tarih 41638 sayılı yazısı.

16 Illahiyat Fakültelerinde genellikle asgari 12 saat olan Hadis derslerine seçmeli dersler dahil edilmemiştir.

17 Niyazi Karasar, Bilimsel Araştırma Yöntemleri. (Ankara: Nobel Yayınları, 2011), 109-111. 


\subsection{Veri Toplama Aracı}

ILITAM bölümü öğrencilerinin hadis dersine yönelik tutumları hakkında bilgi edinebilmek için daha önceden örgün Illahiyat eğitimi alanlara yönelik yapılan anket formları ${ }^{18}$ incelenmiş ve ILITAM öğrencilerine yönelik sorular eklenerek geliştirilmiştir. Anket sonuçları tablolar halinde verilerek yorumlanmıştır. Verilerin analizinde SPSS 17.0 programı kullanılmıştır. Yorumlanma aşamasında yüzde ve sayı yöntemi ile analiz yapılmıştır. Kullanılan anket içerisinde "kesinlikle katılıyorum" "katılıyorum", "kararsızım", "katılmıyorum", "Kesinlikle Katılmıyorum" şeklinde likert tarzında 46 soru sorulmuştur. Ankette yer alan sorulara güvenilirlik analizi olarak Cronbach's Alpha testi uygulanmıştır. Bu testin sonucunda çalışmanın güvenirlik katsayısı 0,71 olarak bulunmuş ve anketin güvenilir olduğu görülmüştür. Araştırma soruları Kocaeli Üniversitesi Illahiyat Fakültesinin 08/02/2021 tarih ve -E-93410193-604.02-17030 sayılı yazısı gereği etik kurul kararı çerçevesinde izin alınarak yapılmıştır.

\section{Bulgular}

\section{1. iLiTAM Bölümü Öğrencilerinin Hadis Dersi Beklentilerine Yönelik Bulgular}

\begin{tabular}{lll}
\hline \multicolumn{3}{c}{ Tablo 1. Hadis Derslerinde sıkılıım } \\
\hline Kesinlikle Katılmıyorum & $\mathrm{N}$ & Yüzde \\
\hline Katılmıyorum & 117 & 47,4 \\
\hline Kararsızım & 109 & 44,1 \\
\hline Katılıyorum & 15 & 6,1 \\
\hline Kesinlikle Katılıyorum & 4 & 1,6 \\
\hline Toplam & 2 & 8, \\
\hline
\end{tabular}


ILITAM Bölümü öğrencilerine "hadis derslerinden sıkılıp sıkılmadıkları" sorulmuş öğrencilerin \% 47,4'ü "kesinlikle katılmıyorum", \%44,1'i "katılmıyorum" cevabını verirken, \% 6,1'i "kararsızım", \% 1,6'sı "katılıyorum", \% 0,8'i "kesinlikle katılıyorum" demiştir. Bu sonuçlara göre öğrencilerin \% 91,5'i hadis dersinden sıkılmadıklarını belirtmiştir.

Tablo 2. Hadis Metinleri Derslerinde edindiğim bilgilerin mezun olduktan sonra işime yarayacağını düşünmüyorum

\begin{tabular}{lll}
\hline & $\mathrm{N}$ & Yüzde \\
\hline Kesinlikle Katılmıyorum & 122 & 49,4 \\
\hline Katılmıyorum & 54 & 21,9 \\
\hline Kararsızım & 7 & 2,8 \\
\hline Katılıyorum & 23 & 9,3 \\
\hline Kesinlikle Katılıyorum & 41 & 16,6 \\
\hline Toplam & 247 & 100,0 \\
\hline
\end{tabular}

Öğrencilere "Hadis Metinleri Derslerinde edindikleri bilgilerin mezun olduktan sonra işine yarayıp yaramayacağı" sorulmuş öğrencilerin \% 49,4'ü "kesinlikle katılmıyorum", \%21,9'u "katılmıyorum" cevabını verirken, \% 2,8'i "kararıızım", \% 9,3'ü katılıyorum, \% 16,6'sı "kesinlikle katılıyorum" demiştir. Bu sonuçlara göre öğrencilerin \% 71,3 'ü hadis derslerinin mezun olduktan sonra işlerine yarayacağını belirtmiştir.

\begin{tabular}{lll}
\hline \multicolumn{2}{c}{ Tablo 3. Hadis Derslerinin haftalık programdaki ders saati arttırılmalıdır } \\
\hline Kesinlikle Katılmıyorum & $\mathrm{N}$ & Yüzde \\
\hline Katılmıyorum & 3 & 1,2 \\
\hline Kararsızım & 50 & 20,2 \\
\hline Katılıyorum & 53 & 21,5 \\
\hline Kesinlikle Katılıyorum & 96 & 38,9 \\
\hline Toplam & 45 & 18,2 \\
\hline
\end{tabular}

"Hadis dersinin haftalık programdaki saatinin arttırılıp arttırılmaması" öğrencilere sorulmuş öğrencilerin \% 1,2'si "kesinlikle katılmıyorum", \% 20,2'si "katılmıyorum" cevabını verirken, \% 21,5'i "kararsızım", \% 38,9'u "katılıyorum", \% 18,2'si "kesinlikle katılıyorum" demiştir. Bu sonuçlara göre öğrencilerin \% 57,1'i hadis derslerinin ders saatlerinin arttııımasını istemiştir. 
Tablo 4. Gelecekteki meslek hayatımda hadis bilgisi önemlidir

\begin{tabular}{lll}
\hline & N & Yüzde \\
\hline Kesinlikle Katılmıyorum & 5 & 2,0 \\
\hline Katılmıyorum & 1 & 4, \\
\hline Kararsızım & 5 & 2,0 \\
\hline Katılıyorum & 54 & 21,9 \\
\hline Kesinlikle Katılıyorum & 182 & 73,7 \\
\hline Toplam & 247 & 100,0 \\
\hline
\end{tabular}

Öğrencilere "gelecekteki meslek hayatlarında hadis bilgisinin önemli olup olmadığı" sorulmuş öğrencilerin \% 2'si "kesinlikle katılmıyorum", \% 0,4'ü "katılmıyorum" cevabını verirken, \% 2'si "kararsızım", \% 21,9'u "katılıyorum", \% 73,7'si "kesinlikle katılıyorum" demiştir. Bu sonuçlara göre öğrencilerin \% 95,6'sı hadis bilgisinin gelecekteki meslek hayatlarında önemli olduğunu belirtmiştir.

\begin{tabular}{lll}
\hline \multicolumn{3}{c}{ Tablo 5. Hadis Derslerine sadece sınavda başarılı olmak için çalışırım } \\
\hline Kesinlikle Katılmıyorum & $\mathrm{N}$ & Yüzde \\
\hline Katılmıyorum & 127 & 51,4 \\
\hline Kararsızım & 101 & 40,9 \\
\hline Katılıyorum & 9 & 3,6 \\
\hline Kesinlikle Katılıyorum & 5 & 2,0 \\
\hline Toplam & 5 & 2,0 \\
\hline
\end{tabular}

ILITAM Bölümünde okuyan öğrencilere "Hadis derslerine sadece sınav için çalışıp çalışmadıkları" sorulmuş öğrencilerin \% 51,4'ü "kesinlikle katılmıyorum", \% 40,9'u "katılmıyorum" cevabını verirken, \% 3,6'sı "kararsızım", \% 2'si "katılıyorum", \% 2'si "kesinlikle katılıyorum" demiştir. Bu sonuçlara göre öğrencilerin \%92,3'ü hadis derslerine sadece sınavda başarılı olmak için çalışmadıklarını belirtmiştir. 


\begin{tabular}{lll}
\hline \multicolumn{3}{c}{ Tablo 6. Hadis bilgisi günlük hayatımda işe yaramaz } \\
\hline Kesinlikle Katılmıyorum & $\mathrm{N}$ & Yüzde \\
\hline Katılmıyorum & 178 & 72,1 \\
\hline Kararsızım & 63 & 25,5 \\
\hline Katılıyorum & 3 & 1,2 \\
\hline Kesinlikle Katılıyorum & 1 &, 4 \\
\hline Toplam & 2 &, 8 \\
\hline
\end{tabular}

"Hadis bilgisinin günlük hayatlarında işe yarayıp yaramadığı" öğrencilere sorulmuş öğrencilerin \% 72,1'i "kesinlikle katılmıyorum", \% 25,5'i "katılmıyorum" cevabını verirken, \% 1,2'i "kararsızım", \% 0,4'ü "katılıyorum", \% 0,8'i "kesinlikle katılıyorum" demiştir. Bu sonuçlara göre öğrencilerin \% 97,6'sı hadis bilgisinin günlük hayatlarında gerekli olduğunu ifade etmişlerdir.

\begin{tabular}{lll}
\hline \multicolumn{2}{c}{ Tablo 7. Ilahiyat Önlisans'ta Hadis Usulü ile ilgili okuduğum kaynaklar yeterlidir. } \\
\hline Kesinlikle Katılmıyorum & $\mathrm{N}$ & Yüzde \\
\hline Katılmıyorum & 66 & 26,7 \\
\hline Kararsızım & 121 & 49,0 \\
\hline Katılıyorum & 35 & 14,2 \\
\hline Kesinlikle Katılıyorum & 18 & 7,3 \\
\hline Toplam & 7 & 2,8 \\
\hline
\end{tabular}

Öğrencilere "Ilahiyat Önlisans'ta Hadis Usulü ile ilgili okudukları kaynakların yeterli olup olmadığı" sorulmuş öğrencilerin \% 26,7'si "kesinlikle katılmıyorum", \% 49'u "katılmıyorum" cevabını verirken, \% 14,2'si "kararsızım", \% 7,3'ü "katılıyorum", \% 2.8'i "kesinlikle katılıyorum" demiştir. Bu sonuçlara göre öğrencilerin \% 75,7'si İlahiyat Önlisans'ta Hadis Usulü ile ilgili okudukları kaynakların yeterli olmadığını ifade etmiştir. 


\begin{tabular}{|c|c|c|}
\hline & $\mathrm{N}$ & Yüzde \\
\hline Kesinlikle Katılmıyorum & 20 & 8,1 \\
\hline Katılmıyorum & 77 & 31,2 \\
\hline Kararsızım & 83 & 33,6 \\
\hline Katılıyorum & 44 & 17,8 \\
\hline Kesinlikle Katılıyorum & 23 & 9,3 \\
\hline Toplam & 247 & 100,0 \\
\hline
\end{tabular}

"Örgün Illahiyat eğitim öğrencilerine göre hadis birikimlerinin yeterli olup olmadığı" ILITAM bölümü öğrencilerine sorulmuş öğrencilerin \% 8,1'i "kesinlikle katılmıyorum", \% 31,2'si "katılmıyorum" cevabını verirken, \% 33,6'sı "kararsızım", \% 18,8'i "katılıyorum", \% 9,3'ü "kesinlikle katılıyorum" demiştir. Bu sonuçlara göre öğrencilerin \% 26,1'i Örgün eğitim öğrencilerine göre hadis birikimlerinin yeterli görmektedir.

Tablo 9. Hadis Metinleri Dersleri hocayla en çok doğrudan iletişim kurma ihtiyacı duyduğum derslerdendir

\begin{tabular}{lll}
\hline & N & Yüzde \\
\hline Kesinlikle Katılmıyorum & 2 &, 8 \\
\hline Katılmıyorum & 33 & 13,4 \\
\hline Kararsızım & 60 & 24,3 \\
\hline Katılıyorum & 103 & 41,7 \\
\hline Kesinlikle Katılıyorum & 49 & 19,8 \\
\hline Toplam & 247 & 100,0 \\
\hline
\end{tabular}

ILITAM Bölümü öğrencilerine "Hadis Metinleri Derslerinin hocayla en çok doğrudan iletişim kurma ihtiyacı duyduğu derslerden olup olmadığı" sorulmuş öğrencilerin \% 0,8'i "kesinlikle katılmıyorum", \% 13,4'ü "katılmıyorum" cevabını verirken, \% 24,3'ü "kararsızım", \% 41,7'si "katılıyorum", \% 19,8'i "kesinlikle katılıyorum" demiştir. Bu sonuçlara göre öğrencilerin \% 61,5'i Hadis Metinleri Derslerinin hocayla en çok doğrudan iletişim kurma ihtiyacı duyduğu derslerden biri olduğunu belirtmiştir. 


\begin{tabular}{lll}
\hline \multicolumn{2}{c}{$\begin{array}{c}\text { Tablo 10. Hadis Metinleri Dersleri esnasında usul konularına yer verilmesi, } \\
\text { dersten alınması gereken mesajı gölgelemektedir }\end{array}$} \\
\hline Kesinlikle Katılmıyorum & $\mathrm{N}$ & Yüzde \\
\hline Katılmıyorum & 43 & 17,4 \\
\hline Kararsızım & 126 & 51,0 \\
\hline Katılıyorum & 46 & 18,6 \\
\hline Kesinlikle Katılıyorum & 25 & 10,1 \\
\hline Toplam & 7 & 2,8 \\
\hline
\end{tabular}

Öğrencilere "Hadis Metinleri Dersleri esnasında usul konularına yer verilmesi, dersten alınması gereken mesajı gölgeleyip gölgelemediği" sorulmuş öğrencilerin \% 17,4'ü "kesinlikle katılmıyorum", \%51'i "katılmıyorum" cevabını verirken, \% 18,6'sı "kararsızım", \% 10,1'i "katılıyorum", \% 2,8'i "kesinlikle katılıyorum" demiştir. Bu sonuçlara göre öğrencilerin \% 68,4'ü Hadis Metinleri Dersleri esnasında usul konularına yer verilmesinin, dersten alınması gereken mesajı gölgelemediğini belirtmiştir.

\subsection{ILITAM Bölümü Öğrencilerinin Hadis Usulü, Hadis Tarihi ve Hadis ilimleri Birikimlerine Yönelik Bulgular}

\begin{tabular}{lll}
\hline \multicolumn{3}{c}{ Tablo 10. Hadis ile ilgili kavramları biliyorum } \\
\hline Kesinlikle Katılmıyorum & $\mathrm{N}$ & Yüzde \\
\hline Katılmıyorum & 5 & 2,0 \\
\hline Kararsızım & 31 & 12,6 \\
\hline Katılıyorum & 64 & 25,9 \\
\hline Kesinlikle Katılıyorum & 131 & 53,0 \\
\hline Toplam & 16 & 6,5 \\
\hline
\end{tabular}

"Hadis ile ilgili kavramları bilip bilmedikleri" öğrencilere sorulmuş öğrencilerin \% 2'si "kesinlikle katılmıyorum", \% 12,6'sı "katılmıyorum" cevabını verirken, \% 25,9'u "kararsızım", \% 53'ü "katılıyorum", \% 6,5'i "kesinlikle katılıyorum" demiştir. Bu sonuçlara göre öğrencilerin \% 59,5'i hadis ile ilgili kavramları bildiklerini ifade etmişlerdir. 


\begin{tabular}{lll}
\hline \multicolumn{3}{c}{ Tablo 12. Vahiy ve sünnet arasındaki ilişkiyi açılayabiliyorum } \\
\hline Kesinlikle Katılmıyorum & $\mathrm{N}$ & Yüzde \\
\hline Katılmıyorum & 2 &, 8 \\
\hline Kararsızım & 4 & 1,6 \\
\hline Katılıyorum & 16 & 6,5 \\
\hline Kesinlikle Katılıyorum & 154 & 62,3 \\
\hline Toplam & 71 & 28,7 \\
\hline
\end{tabular}

ILITAM Bölümünde okuyan öğrencilere "Vahiy ve sünnet arasındaki ilişkiyi açıklayıp açıklayamayacakları" sorulmuş "öğrencilerin" \% 0,8'i "kesinlikle katılmıyorum", \% 1,6'sı "katılmıyorum" cevabını verirken, \% 6,5'i "kararsızım", \% 62,3'ü "katılıyorum", \% 28,7'si "kesinlikle katılıyorum" demiştir. Bu sonuçlara göre öğrencilerin \% 91'i vahiy-sünnet ilişkisini açıklayabildiklerini ifade etmiştir.

\begin{tabular}{lll}
\hline \multicolumn{3}{c}{ Tablo 13. "Hadis Usulü" kavramının ne ifade ettiğini açıklayabilirim } \\
\hline Kesinlikle Katılmıyorum & $\mathrm{N}$ & Yüzde \\
\hline Katılmıyorum & 2 &, 8 \\
\hline Kararsızım & 5 & 2,0 \\
\hline Katılıyorum & 45 & 18,2 \\
\hline Kesinlikle Katılıyorum & 153 & 61,9 \\
\hline Toplam & 42 & 17,0 \\
\hline
\end{tabular}

Öğrencilere "Hadis Usulü kavramının ne ifade ettiğini açıklayıp açıklayamayacakları" sorulmuş öğrencilerin \% 0,8'i "kesinlikle katılmıyorum", \% 2'si "katılmıyorum" cevabını verirken, \% 18,2'si "kararsızım", \% 61,9'u "katılıyorum", \% 17'si "kesinlikle katılıyorum" demiştir. Bu sonuçlara göre öğrencilerin \% 78,9'u Hadis Usulü kavramının ne ifade ettiğini açıklayabildiklerini belirtmiş̧ir. 


\begin{tabular}{lll}
\hline $\begin{array}{r}\text { Tablo 14. Hadis Usulünde âhad, mütevâtir, sahîh, hasen, zayıf, kavramlarının } \\
\text { ne ifade ettiğini muhatabımı ikna edecek şekilde açıklayabilirim }\end{array}$ \\
\hline Kesinlikle Katılmıyorum & N & Yüzde \\
\hline Katılmıyorum & 2 &, 8 \\
\hline Kararsızım & 25 & 10,1 \\
\hline Katılıyorum & 56 & 22,7 \\
\hline Kesinlikle Katılıyorum & 130 & 52,6 \\
\hline Toplam & 34 & 13,8 \\
\hline
\end{tabular}

"Hadis Usulünde âhad, mütevâtir, sahîh, hasen, zayıf, kavramlarının ne ifade ettiğini muhatabımı ikna edecek şekilde açıklayıp açıklayamayacakları" öğrencilere sorulmuş öğrencilerin \% 0,8'i "kesinlikle katılmıyorum", \% 10,1'i "katılmıyorum" cevabını verirken, \% 22,7'si "kararsızım", \% 52,6'sı "katılıyorum", \% 13,8'i "kesinlikle katılıyorum" demiştir. Bu sonuçlara göre öğrencilerin \% 66,4'ü Hadis Usulünde âhad, mütevâtir, sahîh, hasen, zayıf, kavramlarının ne ifade ettiğini muhatabımı ikna edecek şekilde açıklayabileceklerini belirtmiştir.

\begin{tabular}{lll}
\hline \multicolumn{3}{c}{$\begin{array}{c}\text { Tablo 15. Bir hadisin "sahîh" olarak kabul edilmesi için } \\
\text { hangi şartları taşıması gerektiğini biliyorum }\end{array}$} \\
\hline N & Yüzde \\
\hline Kesinlikle Katılmıyorum & 2 &, 8 \\
\hline Katılmıyorum & 9 & 3,6 \\
\hline Kararsızım & 30 & 12,1 \\
\hline Katılıyorum & 155 & 62,8 \\
\hline Kesinlikle Katılıyorum & 51 & 20,6 \\
\hline Toplam & 247 & 100,0 \\
\hline
\end{tabular}

ILITAM Bölümü öğrencilerine "Bir hadisin "sahîh" olarak kabul edilmesi için hangi şartları taşıması gerektiğini bilip bilmedikleri" sorulmuş öğrencilerin \% 0, 8'i "kesinlikle katılmıyorum", \% 3,6'sı "katılmıyorum" cevabını verirken, \% 12,1'i "kararsızım", \% 62,8'i "katılıyorum", \% 20,6'sı "kesinlikle katılıyorum" demiştir. Bu sonuçlara göre öğrencilerin \% 83,4'ü "bir hadisin "sahih" olarak kabul edilmesi için hangi şartları taşıması gerektiğini bildiklerini” ifade etmiştir. 
Tablo 16. Mütekaddimûn Dönemi Hadis Usulü kitaplarının temel niteliklerini biliyorum

\begin{tabular}{lll}
\hline & N & Yüzde \\
\hline Kesinlikle Katılmıyorum & 9 & 3,6 \\
\hline Katılmıyorum & 71 & 28,7 \\
\hline Kararsızım & 93 & 37,7 \\
\hline Katılıyorum & 67 & 27,1 \\
\hline Kesinlikle Katılıyorum & 7 & 2,8 \\
\hline Toplam & 247 & 100,0 \\
\hline
\end{tabular}

"Mütekaddimûn Dönemi Hadis Usulü kitaplarının temel niteliklerini bilip bilmedikleri" öğrencilere sorulmuş öğrencilerin \% 3,6'sı "kesinlikle katılmıyorum", \% 28,7'si "katılmıyorum" cevabını verirken, \% 37,7'si "kararsızım", \% 27,1'i "katılıyorum", \% 2,8'i kesinlikle katılıyorum demiştir. Bu sonuçlara göre öğrencilerin \% 29,9'u Mütekaddimûn Dönemi Hadis Usulü kitaplarının temel niteliklerini bildiklerini belirtmiştir.

\begin{tabular}{|c|c|c|}
\hline & $\mathrm{N}$ & Yüzde \\
\hline Kesinlikle Katılmıyorum & 10 & 4,0 \\
\hline Katılmıyorum & 68 & 27,5 \\
\hline Kararsızım & 98 & 39,7 \\
\hline Katılıyorum & 63 & 25,5 \\
\hline Kesinlikle Katılıyorum & 8 & 3,2 \\
\hline Toplam & 247 & 100,0 \\
\hline
\end{tabular}

ILITAM Bölümü öğrencilerine "Mütekaddimûn ve Müteahhirûn Dönemi Hadis Usulü kitaplarına birer örnek verip veremeyecekleri" sorulmuş öğrencilerin \% 4'ü kesinlikle katılmıyorum, \% 27,5'i katılmıyorum cevabını verirken, \% 39,7'si kararsızım, \% 25,5'i katılıyorum, \% 3,2'si kesinlikle katılıyorum demiştir. Bu sonuçlara göre öğrencilerin \% 28,7'si Mütekaddimûn ve Müteahhirûn Dönemi Hadis Usulü kitaplarına birer örnek verebileceğini ifade etmiştir. 


\begin{tabular}{lll}
\hline \multicolumn{3}{c}{ Tablo 18. En çok rivayette bulunan beş sahabe râvisinin isimlerini sayabilirim } \\
\hline Kesinlikle Katılmıyorum & $\mathrm{N}$ & Yüzde \\
\hline Katılmıyorum & 2 & 8, \\
\hline Kararsızım & 9 & 3,6 \\
\hline Katılıyorum & 33 & 13,4 \\
\hline Kesinlikle Katılıyorum & 143 & 57,9 \\
\hline Toplam & 60 & 24,3 \\
\hline
\end{tabular}

ILITAM Bölümü öğrencilerine "En çok rivayette bulunan beş sahabe râvisinin isimlerini sayıp sayamayacakları" sorulmuş öğrencilerin \% 0,8'i "kesinlikle katılmıyorum", \% 3,6'sı "katılmıyorum" cevabını verirken, \% 13,4'ü "kararsızım", \% 57,9'u "katılıyorum", \% 24,3'ü "kesinlikle katılıyorum" demiştir. Bu sonuçlara göre öğrencilerin \% 82,2'si En çok rivayette bulunan beş sahabe râvisinin isimlerini sayabileceklerini belirtmiştir.

Tablo 19. Hadis Metinleri Derslerinde Hadis Usulü bilgimin azlığı nedeniyle zorlanıyorum

\begin{tabular}{lll}
\hline & N & Yüzde \\
\hline Kesinlikle Katılmıyorum & 12 & 4,9 \\
\hline Katılmıyorum & 74 & 30,0 \\
\hline Kararsızım & 47 & 19,0 \\
\hline Katılıyorum & 92 & 37,2 \\
\hline Kesinlikle Katılıyorum & 22 & 8,9 \\
\hline Toplam & 247 & 100,0 \\
\hline
\end{tabular}

"Hadis Metinleri Derslerinde Hadis Usulü bilgilerinin azlı̆ı nedeniyle zorlanıp zorlanmadıkları" öğrencilere sorulmuş, öğrencilerin \% 4,9'u "kesinlikle katılmıyorum", \% 30'u "katılmıyorum" cevabını verirken, \% 19'u "kararsızım", \% 37,2'si "katılıyorum", \% 8,9'u "kesinlikle katılıyorum" demiştir. Bu sonuçlara göre öğrencilerin $\%$ 46,1'i Hadis Metinleri Derslerinde Hadis Usulü bilgisinin azlığı nedeniyle zorlandıklarını ifade etmiştir. 


\begin{tabular}{lll}
\hline \multicolumn{2}{l}{ Tablo 20. “Riyâzu's-Sâlihîn” adlı eserin kim tarafından yazıldığını ve içeriğini biliyorum } \\
\hline & $\mathrm{N}$ & Yüzde \\
\hline Kesinlikle Katılmıyorum & 3 & 1,2 \\
\hline Katılmıyorum & 15 & 6,1 \\
\hline Kararsızım & 32 & 13,0 \\
\hline Katılıyorum & 122 & 49,4 \\
\hline Kesinlikle Katılıyorum & 75 & 30,4 \\
\hline Toplam & 247 & 100,0
\end{tabular}

Öğrencilere "Riyâzu's-Sâlihîn" adlı eserin kim tarafından yazıldığını ve içeriğini bilip bilmedikleri" sorulmuş öğrencilerin \% 1,2'si "kesinlikle katılmıyorum", \% 6,1'i "katılmıyorum" cevabını verirken, \% 13'ü "kararsızım", \% 49,4'ü "katılıyorum", \% 30,4'ü "kesinlikle katılıyorum" demiştir. Bu sonuçlara göre öğrencilerin \% 79,8'ü "Riyâzu's-Sâlihîn" adlı eserin kim tarafından yazıldığını ve içeriğini bildiklerini ifade etmiştir.

\begin{tabular}{lll}
\hline \multicolumn{3}{c}{$\begin{array}{c}\text { Tablo 21. ILITAM ders programına Hadis Usulü ve } \\
\text { Hadis Tarihi dersleri konulmasını istiyorum }\end{array}$} \\
\hline Kesinlikle Katılmıyorum & $\mathrm{N}$ & Yüzde \\
\hline Katılmıyorum & 6 & 2,4 \\
\hline Kararsızım & 13 & 5,3 \\
\hline Katılıyorum & 28 & 11,3 \\
\hline Kesinlikle Katılıyorum & 120 & 48,6 \\
\hline Toplam & 80 & 32,4 \\
\hline
\end{tabular}

ILITAM Bölümü öğrencilerine "ILITAM ders programına Hadis Usulü ve Hadis Tarihi dersleri konulmasını isteyip istemedikleri" sorulmuş öğrencilerin \% 2,4'ü kesinlikle "katılmıyorum", \% 5,3'ü "katılmıyorum" cevabını verirken, \% 11,3'ü "kararsızım", \% 48,6'ı "katılıyorum", \% 32,4'ü "kesinlikle katılıyorum" demiştir. Bu sonuçlara göre öğrencilerin \% 89'u ILITAM ders programına Hadis Usulü ve Hadis Tarihi dersleri konulmasını istediklerini ifade etmiştir. 


\begin{tabular}{lll}
\hline \multicolumn{2}{l}{ Tablo 22. Hadis Metinleri Derslerinde Hadis Tarihi bilgimin azlığı nedeniyle zorlanıyorum. } \\
\hline & N & Yüzde \\
\hline Kesinlikle Katılmıyorum & 9 & 3,6 \\
\hline Katılmıyorum & 62 & 25,1 \\
\hline Kararsızım & 53 & 21,5 \\
\hline Katılıyorum & 98 & 39,7 \\
\hline Kesinlikle Katılıyorum & 25 & 10,1 \\
\hline Toplam & 247 & 100,0
\end{tabular}

"Hadis Metinleri Derslerinde Hadis Tarihi bilgilerinin azlığı nedeniyle zorlanıp zorlanmadıkları" öğrencilere sorulmuş öğrencilerin \% 3,6'sı "kesinlikle katılmıyorum", \% 25,1'i "katılmıyorum" cevabını verirken, \% 21,5'i "kararsızım" \% 39,7'si "katılıyorum", \% 10,1'i "kesinlikle katılıyorum" demiştir. Bu sonuçlara göre öğrencilerin \% 49,8'i Hadis Metinleri Derslerinde Hadis Tarihi bilgilerinin azlığı nedeniyle zorlandıklarını ifade etmiştir.

\begin{tabular}{lll}
\hline \multicolumn{3}{c}{ Tablo 23. "Muhtelifü'l-hadîs" kavramının neyi ifade ettiğini açıklayabilirim } \\
\hline Kesinlikle Katılmıyorum & $\mathrm{N}$ & Yüzde \\
\hline Katılmıyorum & 2 &, 8 \\
\hline Kararsızım & 30 & 12,1 \\
\hline Katılıyorum & 56 & 22,7 \\
\hline Kesinlikle Katılıyorum & 130 & 52,6 \\
\hline Toplam & 29 & 11,7 \\
\hline
\end{tabular}

Öğrencilere "'Muhtelifü'l-hadîs" kavramının neyi ifade ettiğini açıklayıp açıklayamadıkları" sorulmuş öğrencilerin \% 0,8'i "kesinlikle katılmıyorum", \% 12,1'i "katılmıyorum" cevabını verirken, \% 22,7'si "kararsızım", \% 52,6'sı "katılıyorum", \% 11,7 'si "kesinlikle katılıyorum" demiştir. Bu sonuçlara göre öğrencilerin \% 64,3'ü "Muhtelifü'l-hadîs" kavramının neyi ifade ettiğini açıklayabildiklerini ifade etmiştir. 


\section{3. İLiTAM Bölümü Öğrencilerinin Hadis Kaynaklarına Vukufiyetlerine Yönelik Bulgular}

\begin{tabular}{lll}
\hline \multicolumn{2}{l}{ Tablo 24. “Kütüb-ü Tis'a" kavramının ne ifade ettiğini biliyor ve bu kaynakları sayabiliyorum } \\
\hline & $\mathrm{N}$ & Yüzde \\
\hline Kesinlikle Katılmıyorum & 2 &, 8 \\
\hline Katılmıyorum & 28 & 11,3 \\
\hline Kararsızım & 60 & 24,3 \\
\hline Katılıyorum & 96 & 38,9 \\
\hline Kesinlikle Katılıyorum & 61 & 24,7 \\
\hline Toplam & 247 & 100,0 \\
\hline
\end{tabular}

ILITAM Bölümü öğrencilerine "Kütüb-ü Tis'a" kavramının ne ifade ettiğini biliyor ve bu kaynakları sayıp sayamadıkları" sorulmuş öğrencilerin \% 0,8'i "kesinlikle katılmıyorum", \% 11,3'ü "katılmıyorum" cevabını verirken, \% 24,3'ü "kararsızım", \% 38,9'u "katılıyorum", \% 24,7'si "kesinlikle katılıyorum" demiştir. Bu sonuçlara göre öğrencilerin \% 63,6'sı “Kütüb-ü Tis'a” kavramının ne ifade ettiğini bilip ve bu kaynakları sayabildiklerini ifade etmiştir.

Tablo 25. Imam Buhârî́nin eserini oluştururken nasıl bir metodu benimsediğini biliyorum

\begin{tabular}{lll}
\hline & N & Yüzde \\
\hline Kesinlikle Katılmıyorum & 1 &, 4 \\
\hline Katılmıyorum & 15 & 6,1 \\
\hline Kararsızım & 49 & 19,8 \\
\hline Katılıyorum & 128 & 51,8 \\
\hline Kesinlikle Katılıyorum & 54 & 21,9 \\
\hline Toplam & 247 & 100,0 \\
\hline
\end{tabular}

Öğrencilere "Imam Buhârî́nin eserini oluştururken nasıl bir metodu benimsediğini bilip bilmedikleri" sorulmuş öğrencilerin \% 0,4'ü "kesinlikle katılmıyorum", \% 6,1'i katılmıyorum cevabını verirken, \% 19,8'i "kararsızım", \% 51,8'i "katılıyorum", \% 21,9'u "kesinlikle katılıyorum" demiştir. Bu sonuçlara göre öğrencilerin \% 73,7'si İmam Buhârînin eserini oluştururken nasıl bir metodu benimsediğini bildiklerini ifade etmiştir. 


\begin{tabular}{lll}
\hline \multicolumn{2}{c}{ Tablo 26. Imam Buhârî́nin el-Câmiu's-Sahîh adlı eserinden en az bir bölümü } \\
baştan sona okudum
\end{tabular}

"İmam Buhârî́nin el-Câmiu's-Sahîh adlı eserinden en az bir bölümü baştan sona okudukları" öğrencilere sorulmuş öğrencilerin \% 3,6'sı "kesinlikle katılmıyorum", \% 41,3'ü "katılmıyorum" cevabını verirken, \% 15'i "kararsızım", \% 29,1'i "katılıyorum", \% 10,9'u "kesinlikle katılıyorum" demiştir. Bu sonuçlara göre öğrencilerin \% 40'ı İmam Buhârî́nin el-Câmiu's-Sahîh adlı eserinden en az bir bölümü baştan sona okuduklarını ifade etmiştir.

\section{4. İLiTAM Bölümü Öğrencilerinin Hadis Edebiyatından Yararlanma Kabiliyetine Yönelik Bulgular}

Tablo 27. Bir hadisi açıklarken hangi kaynaklardan yararlanabileceğimi biliyorum

\begin{tabular}{lll}
\hline & N & Yüzde \\
\hline Kesinlikle Katılmıyorum & 3 & 1,2 \\
\hline Katılmıyorum & 35 & 14,2 \\
\hline Kararsızım & 75 & 30,4 \\
\hline Katılıyorum & 105 & 42,5 \\
\hline Kesinlikle Katılıyorum & 29 & 11,7 \\
\hline Toplam & 247 & 100,0 \\
\hline
\end{tabular}

İITAM Bölümü öğrencilerine "Bir hadisi açıklarken hangi kaynaklardan yararlanabileceğini bilip bilmedikleri" sorulmuş öğrencilerin \% 1,2'si "kesinlikle katılmıyorum", \% 14,2'si "katılmıyorum" cevabını verirken, \% 30,4'ü "kararsızım", \% 42,5'i "katılıyorum", \% 11,7'si "kesinlikle katılıyorum" demiştir. Bu sonuçlara göre öğrencilerin \% 53,2'si bir hadisi açıklarken hangi kaynaklardan yararlanabileceğini bildiklerini ifade etmiştir. 


\begin{tabular}{lll}
\hline \multicolumn{3}{l}{ Tablo 28. Bir hadisin yer aldığı kaynağı tespit edebilir ve ilgili kaynakta bu hadisi bulabilirim } \\
\hline & $\mathrm{N}$ & Yüzde \\
\hline Kesinlikle Katılmıyorum & 3 & 1,2 \\
\hline Katılmıyorum & 45 & 18,2 \\
\hline Kararsızım & 83 & 33,6 \\
\hline Katılıyorum & 91 & 36,8 \\
\hline Kesinlikle Katılıyorum & 25 & 10,1 \\
\hline Toplam & 247 & 100,0
\end{tabular}

Öğrencilere "Bir hadisin yer aldığı kaynağı tespit edip ve ilgili kaynakta bu hadisi bulup bulamayacakları" sorulmuş öğrencilerin \% 1,2'si "kesinlikle katılmıyorum", \% 18,2'si "katılmıyorum" cevabını verirken, \% 33,6'sı "kararsızım", \% 36,8'i "katılıyorum", \% 10,1'i "kesinlikle katılıyorum" demiştir. Bu sonuçlara göre öğrencilerin \% 46,9'u bir hadisin yer aldığı kaynağı tespit edebileceğini ve ilgili kaynakta bu hadisi bulabileceğini ifade etmiştir.

\section{5. İLiTAM Bölümü Öğrencilerinin Hadis Dersinin Diğer İslami ilimleri Anlamaya Katkısına Yönelik Bulgular}

\begin{tabular}{lll}
\hline \multicolumn{3}{c}{$\begin{array}{c}\text { Tablo 29. Hadis Metinleri Derslerinde edindiğim birikim, İslam Hukuku kapsamında } \\
\text { karşılaştı̆ım sorulara daha rahat cevap vermemi sağlar }\end{array}$} \\
\hline N & Yüzde \\
\hline Kesinlikle Katılmıyorum & 1 &, 4 \\
\hline Katılmıyorum & 13 & 5,3 \\
\hline Kararsızım & 40 & 16,2 \\
\hline Katılıyorum & 134 & 54,3 \\
\hline Kesinlikle Katılıyorum & 59 & 23,9 \\
\hline Toplam & 247 & 100,0 \\
\hline
\end{tabular}

"Hadis Metinleri Derslerinde edindikleri birikimin, İslam Hukuku kapsamında karşılaştıkları sorulara daha rahat cevap vermelerini sağlayıp sağlamadıkları" öğrencilere sorulmuş öğrencilerin \% 0,4'ü "kesinlikle katılmıyorum", \% 5,3'ü "katılmıyorum" cevabını verirken, \% 16,2'si "kararsızım", \% 54,3'i "katılıyorum", \% 23,9'u "kesinlikle katılıyorum" demiştir. Bu sonuçlara göre öğrencilerin \% 78, 2'si Hadis Metinleri Derslerinde edindikleri birikimin, İslam Hukuku kapsamında karşılaştığı sorulara daha rahat cevap vermelerini sağladığını ifade etmiştir. 


\begin{tabular}{lll}
\hline \multicolumn{3}{c}{$\begin{array}{c}\text { Tablo 30. Hadis Metinleri Derslerinde edindiğim birikim, Kelam ilmi kapsamında } \\
\text { karşılaştığım sorulara daha rahat cevap vermemi sağlar }\end{array}$} \\
\hline Kesinlikle Katılmıyorum & $\mathrm{N}$ & Yüzde \\
\hline Katılmıyorum & 2 &, 8 \\
\hline Kararsızım & 12 & 4,9 \\
\hline Katılıyorum & 54 & 21,9 \\
\hline Kesinlikle Katılıyorum & 127 & 51,4 \\
\hline Toplam & 52 & 21,1 \\
\hline
\end{tabular}

ILITAM Bölümü öğrencilerine "Hadis Metinleri Derslerinde edindikleri birikimin Kelam ilmi kapsamında karşılaştıkları sorulara daha rahat cevap vermelerini sağlayıp sağlamadıkları" sorulmuş öğrencilerin \% 0,8'i "kesinlikle katılmıyorum", \% 4,9'u "katılmıyorum" cevabını verirken, \% 21,9'u "kararsızım", \% 51,4'ü "katılıyorum", \% 21,1'i "kesinlikle katılıyorum" demiştir. Bu sonuçlara göre öğrencilerin \% 72,5'i Hadis Metinleri Derslerinde edindikleri birikimin, Kelam ilmi kapsamında karşılaştığı sorulara daha rahat cevap vermelerini sağladığını ifade etmiştir.

Tablo 31. Hadis Metinleri Derslerinde edindiğim birikim, Tefsir ilmi kapsamında karşılaştığım sorulara daha rahat cevap vermemi sağlar

\begin{tabular}{lll}
\hline & $\mathrm{N}$ & Yüzde \\
\hline Kesinlikle Katılmıyorum & 14 & 5,7 \\
\hline Katılmıyorum & 32 & 13,0 \\
\hline Kararsızım & 135 & 54,7 \\
\hline Katılıyorum & 66 & 26,7 \\
\hline Kesinlikle Katılıyorum & 52 & 21,1 \\
\hline Toplam & 247 & 100,0 \\
\hline
\end{tabular}

Öğrencilere "Hadis Metinleri Derslerinde edindikleri birikimin Tefsir ilmi kapsamında karşılaştıkları sorulara daha rahat cevap vermelerini sağlayıp sağlamadıkları" sorulmuş öğrencilerin \% 5,7'si "katılmıyorum" cevabını verirken, \% 13'ü "kararsızım", \% 54,7'si "katılıyorum", \% 26,7'si "kesinlikle katılıyorum" demiştir. Bu sonuçlara göre öğrencilerin \% 81,4'ü Hadis Metinleri Derslerinde edindikleri birikimin, Tefsir ilmi kapsamında karşılaştı̆ı̆ı sorulara daha rahat cevap vermelerini sağladığını ifade etmiş̧tir. 


\section{6. İLiTAM Bölümü Öğrencilerinin Hadis Dersinin İçeriği ve Kendi Hayatlarına Etkilerine Yönelik Bulgular}

\begin{tabular}{|c|c|c|}
\hline & $\mathrm{N}$ & Yüzde \\
\hline Kesinlikle Katılmıyorum & 1 & 4 \\
\hline Katılmıyorum & 5 & 2,0 \\
\hline Kararsızım & 86 & 34,8 \\
\hline Katılıyorum & 155 & 62,8 \\
\hline Kesinlikle Katılıyorum & 52 & 21,1 \\
\hline Toplam & 247 & 100,0 \\
\hline
\end{tabular}

"Vahyi anlayabilmek ve uygulayabilmek için sünnetin rehberliğine ihtiyaç duyup duymadıkları" öğrencilere sorulmuş öğrencilerin \% 0,4'ü "kesinlikle katılmıyorum", \% 2'si "katılmıyorum" cevabını verirken, \% 34,8'i "katılıyorum", \% 62,8'i "kesinlikle katılıyorum" demiştir. Bu sonuçlara göre öğrencilerin \% 97,6'sı Vahyi anlayabilmek ve uygulayabilmek için sünnetin rehberliğine ihtiyaç duyduklarını ifade etmiştir.

Tablo 33. Anlamakta zorlandığım bir rivayetle karşılaştığımda, onun $\mathrm{Hz}$. Peygamber tarafından söylenmiş olamayacağını kabul ederim

\begin{tabular}{lll}
\hline & $\mathrm{N}$ & Yüzde \\
\hline Kesinlikle Katılmıyorum & 34 & 13,8 \\
\hline Katılmıyorum & 75 & 30,4 \\
\hline Kararsızım & 95 & 38,5 \\
\hline Katılıyorum & 33 & 13,4 \\
\hline Kesinlikle Katılıyorum & 10 & 4,0 \\
\hline Toplam & 247 & 100,0 \\
\hline
\end{tabular}

ILITAM Bölümü öğrencilerine "Anlamakta zorlandığı bir rivayetle karşılaştığında, onun $\mathrm{Hz}$. Peygamber tarafından söylenmiş olamayacağını kabul edip etmedikleri" sorulmuş öğrencilerin \% 13,8'i" kesinlikle katılmıyorum", \% 30,4'ü "katılmıyorum" cevabını verirken, \% 38,5'i "kararsızım" \% 13,4'ü "katılıyorum", \% 4'ü "kesinlikle katılıyorum" demiştir. Bu sonuçlara göre öğrencilerin \% 17,4'ü anlamakta zorlandığı bir rivayetle karşılaştığında, onun $\mathrm{Hz}$. Peygamber tarafından söylenmiş olamayacağını kabul ettiklerini ifade etmiştir. 


\begin{tabular}{lll}
\hline \multicolumn{3}{c}{ Tablo 34. Hadis Usulü ile ilgili -ders kitabı haricinde- Türkçe bir eser okudum } \\
\hline Kesinlikle Katılmıyorum & N & Yüzde \\
\hline Katılmıyorum & 10 & 4,0 \\
\hline Kararsızım & 110 & 44,5 \\
\hline Katılıyorum & 35 & 14,2 \\
\hline Kesinlikle Katılıyorum & 78 & 31,6 \\
\hline Toplam & 14 & 5,7 \\
\hline
\end{tabular}

Öğrencilere "Hadis Usulü ile ilgili -ders kitabı haricinde- Türkçe bir eser okuyup okumadıkları" sorulmuş öğrencilerin \% 4'ü "kesinlikle katılmıyorum", \% 44,5'i "katılmıyorum" cevabını verirken, \% 14,2'si "kararsızım" \% 31,6'sı "katılıyorum", \% 5,7'si "kesinlikle katılıyorum" demiştir. Bu sonuçlara göre öğrencilerin \% 36,3'ü Hadis Usulü ile ilgili -ders kitabı haricinde-Türkçe bir eser okuduklarını ifade etmiştir.

\begin{tabular}{lll}
\hline \multicolumn{3}{c}{ Tablo 35. Hadis Tarihi ile ilgili -ders kitabı haricinde- Türkçe bir eser okudum } \\
\hline Kesinlikle Katılmıyorum & $\mathrm{N}$ & Yüzde \\
\hline Katılmıyorum & 16 & 6,5 \\
\hline Kararsızım & 117 & 47,4 \\
\hline Katılıyorum & 37 & 15,0 \\
\hline Kesinlikle Katılıyorum & 65 & 26,3 \\
\hline Toplam & 12 & 4,9 \\
\hline
\end{tabular}

"Hadis Tarihi ile ilgili -ders kitabı haricinde- Türkçe bir eser okuyup okumadıkları" öğrencilere sorulmuş öğrencilerin \% 6,5'i "kesinlikle katılmıyorum", \% 47,4'ü "katılmıyorum" cevabını verirken, \% 15'i "kararsızım" \% 26,3'sı "katılıyorum", \% 4,9'u "kesinlikle katılıyorum" demiştir. Bu sonuçlara göre öğrencilerin \% 31,2'si Hadis Tarihi ile ilgili -ders kitabı haricinde- Türkçe bir eser okuduklarını ifade etmişken $\%$ 53,8'i de okumadıklarını ifade etmiştir. 
Tablo 36. Illahiyat eğitimi almış biri olarak, bir topluluğa konuşma yaparken ahlakla ilgili en az üç hadisi metne bağlı kalmadan okuyabilirim

\begin{tabular}{lll}
\hline & N & Yüzde \\
\hline Kesinlikle Katılmıyorum & 2 &, 8 \\
\hline Katılmıyorum & 18 & 7,3 \\
\hline Kararsızım & 52 & 21,1 \\
\hline Katılıyorum & 129 & 52,2 \\
\hline Kesinlikle Katılıyorum & 46 & 18,6 \\
\hline Toplam & 247 & 100,0 \\
\hline
\end{tabular}

ILITAM Bölümü öğrencilerine "Illahiyat eğitimi almış biri olarak, bir topluluğa konuşma yaparken ahlakla ilgili en az üç hadisi metne bağlı kalmadan okuyup okuyamayacakları" sorulmuş öğrencilerin \% 0,8'i "kesinlikle katılmıyorum", \% 7,3'ü "katılmıyorum" cevabını verirken, \% 21,1'i "kararsızım" \% 52,2'si "katılıyorum", \% 18,6'sı "kesinlikle katılıyorum" demiştir. Bu sonuçlara göre öğrencilerin \% 70,8'i Illahiyat eğitimi almış biri olarak, bir topluluğa konuşma yaparken ahlakla ilgili en az üç hadisi metne bağlı kalmadan okuduklarını ifade etmiştir.

\begin{tabular}{lll}
\hline \multicolumn{2}{c}{ Tablo 37. Ilahiyat eğitimim sırasında Hadis Tarihi ile ilgili edindiğimiz bilgiler ve } \\
okuduğumuz kaynaklar yeterlidir
\end{tabular}

Öğrencilere "Illahiyat eğitimi sırasında Hadis Tarihi ile ilgili edindikleri bilgiler ve okudukları kaynakların yeterli olup olmadığı" sorulmuş, öğrencilerin \% 10,5'i "kesinlikle katılmıyorum", \% 34,4'ü "katılmıyorum" cevabını verirken, \% 37,2'si "kararsızım" \% 19,4'ü "katılıyorum", \% 2,4'ü "kesinlikle katılıyorum" demiştir. Bu sonuçlara göre öğrencilerin \% 21,8'i İlahiyat eğitimi sırasında Hadis Tarihi ile ilgili edindikleri bilgiler ve okudukları kaynakları yeterli görmüştür. 
Tablo 38. Ilahiyat Fakültesi'nde eğitim almış biri olarak, bir topluluğa konuşma yaparken ibadetle ilgili en az üç hadisi metne bağı kalmadan okuyabilirim

\begin{tabular}{lll}
\hline & $\mathrm{N}$ & Yüzde \\
\hline Kesinlikle Katılmıyorum & 2 &, 8 \\
\hline Katılmıyorum & 20 & 8,1 \\
\hline Kararsızım & 53 & 21,5 \\
\hline Katılıyorum & 119 & 48,2 \\
\hline Kesinlikle Katılıyorum & 53 & 21,5 \\
\hline Toplam & 247 & 100,0 \\
\hline
\end{tabular}

"Illahiyat eğitimi almış biri olarak, bir topluluğa konuşma yaparken ibadetle ilgili en az üç hadisi metne bağlı kalmadan okuyup okuyamayacakları" öğrencilere sorulmuş öğrencilerin \% 0,8'i "kesinlikle katılmıyorum", \% 8,1'i "katılmıyorum" cevabını verirken, \% 21,5'i "kararsızım" \% 48,2'si "katılıyorum", \% 21,5'i "kesinlikle katılıyorum" demiştir. Bu sonuçlara göre öğrencilerin \% 69,7'si ilahiyat eğitimi almış biri olarak, bir topluluğa konuşma yaparken ibadetle ilgili en az üç hadisi metne bağlı kalmadan okuduklarını ifade etmiştir.

Tablo 39. Düzenli çalışan bir öğrenci olmama ve diğer derslerde zorluk yaşamama rağmen Hadis Metinleri Derslerinde zorlanıyorum

\begin{tabular}{lll}
\hline & N & Yüzde \\
\hline Kesinlikle Katılmıyorum & 23 & 9,3 \\
\hline Katılmıyorum & 81 & 32,8 \\
\hline Kararsızım & 52 & 21,1 \\
\hline Katılıyorum & 66 & 26,7 \\
\hline Kesinlikle Katılıyorum & 25 & 10,1 \\
\hline Toplam & 247 & 100,0 \\
\hline
\end{tabular}

ILITAM Bölümü öğrencilerine "Düzenli çalışan bir öğrenci olmalarına ve diğer derslerde zorluk yaşamamasına rağmen Hadis Metinleri Derslerinde zorlanıp zorlanmadıkları" sorulmuş öğrencilerin \% 9,3'ü "kesinlikle katılmıyorum", \% 32,8'i "katılmıyorum" cevabını verirken, \% 21,1'i "kararsızım" \% 26,7'si "katılıyorum", \% 10,1'i "kesinlikle katılıyorum" demiştir. Bu sonuçlara göre öğrencilerin \% 38,1'i düzenli çalışan bir öğrenci olmalarına ve diğer derslerde zorluk yaşamamasına rağmen Hadis Metinleri Derslerinde zorlandıklarını ifade etmiştir. 


\begin{tabular}{lll}
\hline \multicolumn{2}{c}{ Tablo 40. ILITAM programında aldığım Arapça dersleri, Hadis Metinleri Derslerini } \\
anlamada yeterli olmaktadır
\end{tabular}

Öğrencilere "ILITAM programında aldıkları Arapça dersleri, Hadis Metinleri Derslerini anlamada yeterli olup olmadığı" sorulmuş öğrencilerin \% 12,6'sı "kesinlikle katılmıyorum", \% 36'sı "katılmıyorum" cevabını verirken, \% 26,3'ü "kararsızım" \% 21,1'i "katılıyorum", \% 4'ü "kesinlikle katılıyorum" demiştir. Bu sonuçlara göre öğrencilerin \% 25,1'i ILITAM programında aldıkları Arapça dersleri, Hadis Metinleri Derslerini anlamada yeterli olduğunu ifade etmiştir.

Tablo 41. Hadis Dersinin sünneti doğru anlamada faydalı olacağını düşünüyorum

\begin{tabular}{lll}
\hline & N & Yüzde \\
\hline Kesinlikle Katılmıyorum & 1 &, 4 \\
\hline Katılmıyorum & 2 & 8, \\
\hline Kararsızım & 4 & 1,6 \\
\hline Katılıyorum & 79 & 32,0 \\
\hline Kesinlikle Katılıyorum & 161 & 65,2 \\
\hline Toplam & 247 & 100,0 \\
\hline
\end{tabular}

İLITAM Bölümü öğrencilerine "Hadis Dersinin sünneti doğru anlamada faydalı olup olmayacağı" sorulmuş öğrencilerin \% 0,4'ü "kesinlikle katılmıyorum", \% 0.8'i "katılmıyorum" cevabını verirken, \% 1,6'sı "kararsızım", \% 32'si "katııyorum", \% 65,2'si "kesinlikle katılıyorum" demiştir. Bu sonuçlara göre öğrencilerin \% 97,2'si Hadis Dersinin sünneti doğru anlamada faydalı olduğunu ifade etmiştir. 


\begin{tabular}{|c|c|c|}
\hline & $\mathrm{N}$ & Yüzde \\
\hline Kesinlikle Katılmıyorum & 14 & 5,7 \\
\hline Katılmıyorum & 55 & 22,3 \\
\hline Kararsızım & 34 & 13,8 \\
\hline Katılıyorum & 101 & 40,9 \\
\hline Kesinlikle Katılıyorum & 43 & 17,4 \\
\hline Toplam & 247 & 100,0 \\
\hline
\end{tabular}

Öğrencilere "Hadis Metinleri Derslerinde Arapça eğitimleri/seviyeleri yeterli olmadığı için zorlanıp zorlanmadıkları" sorulmuş öğrencilerin \% 5,7'si "kesinlikle katılmıyorum", \% 22,3'ü "katılmıyorum" cevabını verirken, \% 13,8'i "kararsızım", \% 40,9'u "katılıyorum", \% 17,4'ü "kesinlikle katılıyorum" demiştir. Bu sonuçlara göre öğrencilerin \% 58,3'ü Hadis Metinleri Derslerinde Arapça eğitimleri/seviyeleri yeterli olmadığı için zorlandıklarını ifade etmiştir.

\begin{tabular}{lll}
\hline \multicolumn{2}{c}{ Tablo 43. Hadis Derslerinde öğrendiğim hadisler, ibadetlerimde daha dikkatli } \\
davranmamı temin eder
\end{tabular}

"Hadis derslerinde öğrendikleri hadislerin, ibadetlerinde daha dikkatli davranmalarını temin edip etmedikleri" öğrencilere sorulmuş öğrencilerin \% 0,8'i "kesinlikle katılmıyorum", \% 1,2'si "katılmıyorum" cevabını verirken, \% 4,9'u "kararsızım" \% 49,8'i "katılıyorum", \% 43,3'ü "kesinlikle katılıyorum" demiştir. Bu sonuçlara göre öğrencilerin \% 93,1'i hadis derslerinde öğrendikleri hadislerin, ibadetlerinde daha dikkatli davranmalarını temin ettiğini ifade etmiştir. 


\section{7. İLiTAM Bölümü Öğrencilerinin Medya ve Hadis İlişkisine Yönelik Bulgular}

\begin{tabular}{lll}
\hline \multicolumn{2}{c}{ Tablo 44. Sosyal medyada düzenli olarak (her Cuma, önemli gün ve gecelerde vb.) } \\
hadis paylaşırım
\end{tabular}

ILITAM Bölümü öğrencilerine "Sosyal medyada düzenli olarak (her Cuma, önemli gün ve gecelerde vb.) hadis paylaşıp paylaşmadıkları" sorulmuş öğrencilerin \% 10,1'i "kesinlikle katılmıyorum", \% 43,7'si "katılmıyorum" cevabını verirken, \% 18,2'i "kararsızım" \% 22,3'ü "katılıyorum", \% 5,7'si "kesinlikle katılıyorum" demiştir. Bu sonuçlara göre öğrencilerin \% 28'i sosyal medyada düzenli olarak (her Cuma, önemli gün ve gecelerde vb.) hadis paylaştıklarını ifade etmiştir.

\begin{tabular}{lll}
\hline \multicolumn{2}{c}{$\begin{array}{c}\text { Tablo 45. Sosyal medyada hadis olarak paylaşılan sözlerin, gerçekten hadis } \\
\text { kaynaklarında nakledilip nakledilmediğini sorgulamadan hadis olduğuna inanırım }\end{array}$} \\
\hline Kesinlikle Katılmıyorum & $\mathrm{N}$ & Yüzde \\
\hline Katılmıyorum & 94 & 38,1 \\
\hline Kararsızım & 123 & 49,8 \\
\hline Katılıyorum & 20 & 8,1 \\
\hline Kesinlikle Katılıyorum & 9 & 3,6 \\
\hline Toplam & 1 &, 4 \\
\hline
\end{tabular}

Öğrencilere "Sosyal medyada hadis olarak paylaşılan sözlerin, gerçekten hadis kaynaklarında nakledilip nakledilmediğini sorgulamadan hadis olduğuna inanıp inanmadıkları" sorulmuş öğrencilerin \% 38,1'i "kesinlikle katılmıyorum", \% 49,8'i "katılmıyorum" cevabını verirken, \% 8,1'i "kararsızım" \% 3,6'u "katılıyorum", \% 0,4'ü "kesinlikle katılıyorum" demiştir. Bu sonuçlara göre öğrencilerin \% 87,9'u Sosyal medyada hadis olarak paylaşılan sözlerin, gerçekten hadis kaynaklarında nakledilip nakledilmediğini sorgulamadan hadis olduğuna inanmadıklarını ifade etmiştir. 


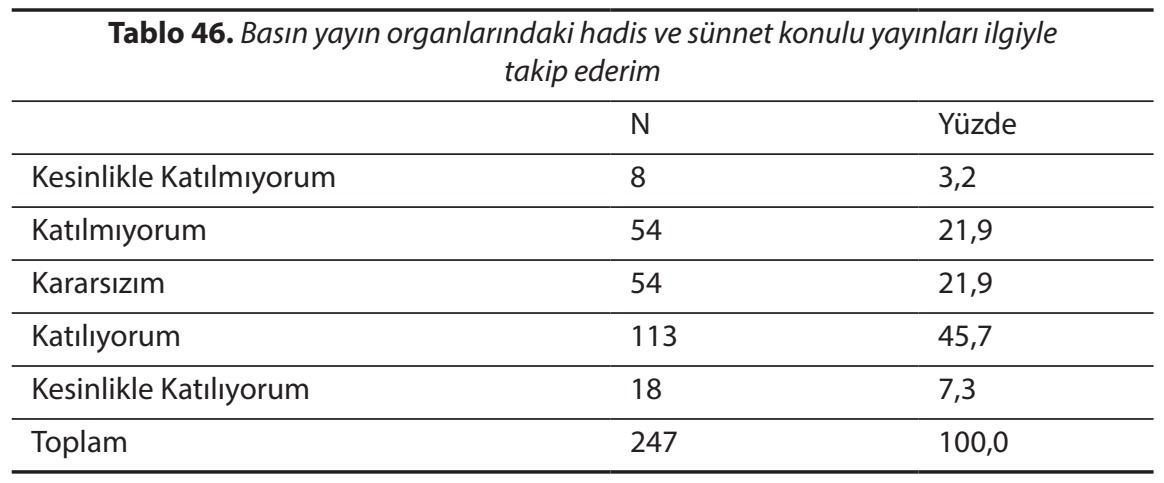

"Basın yayın organlarındaki hadis ve sünnet konulu yayınları ilgiyle takip edip etmedikleri" öğrencilere sorulmuş öğrencilerin \% 3,2'si "kesinlikle katılmıyorum", \% 21,9'u "katılmıyorum" cevabını verirken, \% 21,9'u "kararsızım" \% 45,7'si "katılıyorum", \% 7,3'ü "kesinlikle katılıyorum" demiştir. Bu sonuçlara göre öğrencilerin \% 53'ü basın yayın organlarındaki hadis ve sünnet konulu yayınları ilgiyle takip ettiklerini ifade etmiştir.

\section{Sonuç}

2021 yılı itibariyle Türkiye'de Illahiyat Fakültesi ve İslami Ilimler Fakültesi adları altında eğitim veren 116 Yüksek din öğretimi kurumu ve yaklaşık 10 bin akademik personel bulunmaktadır. ${ }^{19}$ Örgün eğitim, ön lisans ve ILITAM programları dahil yüz elli bini aşkın öğrenci yüksek din öğretimi programlarında okumaktadır. ${ }^{20}$ Böylesine büyük bir eğitim faaliyeti yürüten Illahiyat ve İslami İlimler Fakültelerinin hem gelenekten gelen hem de çağın getirmiş olduğu süreçlerin gereği olarak devletin ve toplumun beklentileri doğrultusunda eğitim niteliklerini geliştirmeleri gerekmektedir. Özellikle büyüyen öğrenci sayıları ile birlikte İLiTAM programları başlangıçta iyi niyetle açılmış olsalar bile günümüzde gelinen noktada ilahiyat alanı ile ilgili temel yeterlilikler konusunda ILITAM mezunlarının örgün ilahiyat mezunlarına göre istenilen düzeyde olmadıkları tespit edilmiştir. ${ }^{21}$ Bununla birlikte Illahiyat fakültelerinin açık öğretim fakültelerine dönüştürülme

19 İlahiyat fakültelerinin sayısı Mart 2021 tarihinde Türkiye'deki üniversitelerin web sitelerine girilerek hesaplanmıştır.

20 Mustafa Kiriş. Illahiyat Fakülteleri ve Diyanet Iş̧leri Başkanlığı Ekseninde Türkiye'de Din Eğitimi, (Ankara: Illâhiyât Yayınevi, 2018), 100.

21 DEM Rapor, s,3-7. 
tehlikesi ${ }^{22}$ ILITAM programları ve eğitimi üzerine daha fazla çalışma yapmayı gerekli kılmaktadır.

İLiTAM bölümü öğrencilerinin hadis dersine yönelik tutumlarının incelendiği bu çalışmada öğrencilerin;

ILITAM programındaki hadis derslerinin sayısının yetersiz olduğunu ifade ettikleri görülmüştür. Öğrenciler, ILITAM programının 2. sınıf birinci ve ikinci yarıyılında ikişer saat olan Hadis Metinleri Derslerinin sayısını yetersiz bulmakta ve artııımasını talep etmektedirler.

İlahiyat ön lisansta okudukları Hadis Tarihi ve Usulü kaynaklarının yetersiz kaldığını belirtmekteler. Ön lisansta okumuş oldukları kaynaklar yetersiz olduğu için bu dersler için takviye istemektedirler. Ders programına onların bu eksiklerini giderici ilave dersler konulabilir.

Araştırma sonucunda İLiTAM bölümü öğrencilerinin kendilerini örgün İlahiyat öğrencilerine göre yetersiz hissettikleri görülmüştür. Bir önceki maddenin sonuçlarından biri olan bu durum genelde ILITAM programında özelde ise Hadis derslerinde kendisini hissettirmektedir.

Öğrencilerin, ILITAM programında yer alan Hadis Metinleri Dersinde hocaların usul konularına girmelerini önemsedikleri görülmüştür. Bu tespit önceki sonuçları doğrular ve destekler mahiyettedir. Hadis Tarihi ve Usulü ile ilgili eksiklerin öğretim elemanları tarafından tamamlanması öğrencileri memnun etmekte ve olumsuz bir durum oluşturmamaktadır. Öğrencilerin bu tutumu aynı zamanda Hadis dersi özelinde öğrenme arzularının yüksek olduğu şeklinde yorumlanabilir. Öğrencilerin, Hadis Edebiyatından yararlanma konularında yetersiz kaldıkları görülmüştür. Örgün eğitimde ders sayısının ve çeşidinin fazla olması bu açığı kapatmaktadır. Örgün eğitimde ders içi ve ders dışı yapılan araştırma ve ödevlerin ILITAM programında yapılamaması Hadis Edebiyatını tanıma ve ondan yararlanma imkânını azaltmaktadır.

Öğrencilerin, Hadis Usulü ve Tarihi konularında ders kitabı haricinde okuma yapmadıkları görülmüştür. Ders kitabı haricinde bir okuma yapmamak genellikle 
merak duymamak veya vakit bulamak nedeniyle olabilir. Bu durum yüz yüze eğitim ve iletişim ile giderilebilir.

Öğrencilerin Arapça eğitimi eksikliklerinden dolayı Hadis Metinleri Derslerinde zorlandıkları sonucu çıkmıştır. ILITAM programında hazırlık programının bulunmaması ve Arapça ders saatlerinin sınırlı olması nedeniyle öğrencilerin Hadis Metinleri Derslerinde zorlandığı söylenebilir.

ILITAM bölümünde okuyan öğrencilerin hadis dersine yönelik tutumlarını örgün Illahiyat bölümü öğrencilerine yönelik yapılan çalışmalarla ${ }^{23}$ karşılaştırdığımızda iki bölüm öğrencilerinin Hadis Usulünün temel kaynaklarına vukufiyet ve Arapça dersleri konusunda yetersiz kaldıkları görülmektedir. Buna karşın örgün Illahiyatta okuyan öğrencilerin Hadis Usulü, Hadis Edebiyatı ve Hadis illimleri konularında İLITAM bölümü öğrencilerine göre daha iyi konumda olduğu sonucu çıkmıştır. Bunun sebebi olarak örgün eğitim öğrencilerinin Hadis Usulü ve Tarihi Derslerinin yanında gördükleri diğer hadis dersleri olduğu söylenebilir. Çünkü ILITAM bölümü öğrencileri toplam dört saat Hadis Metinleri Dersi görürken örgün eğitimde ders saati seçmeli dersler hariç asgari 12 saattir. Seçmeli dersleri ilave ettiğimizde bu saatler daha da artmaktadır.

Bu bağlamda;

ILITAM programı yeniden revize edilerek örgün İlahiyat müfredatı ile uyumlu hale getirilerek programa Hadis Usulü, Hadis Tarihi ve Hadis Edebiyatı gibi dersler konabilir,

Dil altyapısından kaynaklanan eksikler olabildiğince asgariye indirilerek Hadis Metinleri Derslerinin anlaşılırlığı arttırılabilmek için Arapça ders saatleri fazlalaştırılabilir,

İmkânlar ölçüsünde yüz yüze eğitim süresi artırılarak öğrencilerin öğretim elemanları ile doğrudan teması sağlanabilir. Böylece öğrencilerin öğrenmek istedikleri konuları öğretim elemanlarına doğrudan sorma imkânı doğacaktır. Asgari ölçüde de olsa öğretim elemanları ile doğrudan iletişim öğrencilerin bilgi, donanım ve motivasyonları açısından olumlu katkılar sunacaktır.

Sonuç olarak; ILITAM programı mezunları örgün ilahiyat eğitimiyle aynı diplomayı aldıklarından dolayı eğitim açııından da olabildiğince aynı eğitimin verilmesi 
standartlık ve kalite açısından önemlidir. Bu eğitim yapılırken ILITAM programı öğrencilerini örgün ilahiyat öğrencilerine göre negatif ayrımcılık yapmamak ${ }^{24}$ ve bu bölümde öğrenim gören öğrencilerin motivasyonunu yüksek tutmak verilen eğitimin niteliği açısından oldukça önemlidir.

\section{Kaynakça}

"25. Ilâhiyat ve İslâmî Illimler Fakülteleri Dekanlar Toplantısı Sonuç Bildirgesi - İlahiyat Fakültesi". Erişim: 24 Nisan 2021. https://ilahiyat.sinop.edu.tr/25-ilahiyat-ve-islami-ilimler-fakulteleri-dekanlar-toplantisi-sonuc-bildirgesi/.

"26. Illahiyat ve İslami Ilimler Dekanlar Toplantısı Sonuç Bildirisi". adanapost. Erişim: 24 Nisan 2021. https://www.adanapost.com/26-ilahiyat-ve-islami-ilimler-dekanlar-toplantisi-sonuc-bildirisi-139717h.htm.

Altaş, N. “Türkiye'de Dini Yükseköğretim Alanında Uzaktan Eğitimle Illgili Algı Sorunları ve ILITAM Uygulamaları". Değerler Eğitimi Dergisi 14/31 (2016): 7-42

Altun, Emrah. “Eğitmenlerin Uzaktan Eğitime Yönelik Pedagojik Yeterliliklerinin Uzaktan Eğitim Ders Videoları Aracılığıyla İncelenmesi". Yayınlanmamış Yüksek Lisans Tezi, Ondokuz Mayıs Üniversitesi, 2020.

Arkan, Atilla. "Ilahiyat Eğitimi ve Illahiyat Lisans Tamamlama Programları (ILITAM)". SETA. Erişim 28 Aralık 2018. https://www.setav.org/ilahiyat-egitimi-ve-ilahiyat-lisans-tamamlama-programlari-ILITAM/.

Arslan, F, Ö. Korkmaz. ILITAM Lisans Tamamlama Uzaktan Eğitim Öğrencilerinin Etkileşim Kaygıları ve Uzaktan Eğitime Dönük Tutumları. Ahmet Keleşoğlu Eğitim Fakültesi Dergisi, 1/1 (2019): 12-25.

Bunker, E. The History of Distance Education Through the Eyes of The International Council for Distance Education. Ed. M. G. Moore \& W. G. Anderson. Handbook of distance education içinde (ss. 49-66). New Jersey: Lawrence Erlbaum Associates, 2003.

Çakan, I. Lütfi. "ilahiyat Fakültelerinde Hadis Öğretimi”. Yüksek Öğretimde Din Bilimleri Öğretimi Sempozyumu Kitabı içinde. ss. 353-361. Bu bildiri, 21-23 Ekim 1987 tarihleri arasında Samsun'da gerçekleştirilen Yüksek Öğretimde Din Bilimleri Öğretimi Sempozyumu'nda sunulmuştur. Samsun: Ondokuz Mayıs Üniversitesi Yay., 1988.

Değerler Eğitimi Merkezi (DEM) Illahiyat Lisans Tamamlama Programları ile Illgili Geçici Kanun Tasarısı Üzerine Değerlendirme (2018). Erişim 17.02.2019. https://media.dem.org.tr/dir/dem/dem/proje/goruntuleme/20181229152145_0.pdf.

Demirli, E. (2019). Asırlık Bir Müktesebat Yok Olmadan: Illahiyat Fakültelerini Açıöğretim Fakültesi Yapmak. Erişim 20.03.2021. https://www.fikriyat.com/yazarlar/akademi/ekremdemirli/2019/02/10/asirlik-bir-muktesebat-heba-olmadanilahiyat-fakulteleriniacik-ogretim-fakultesi-yapmak.

Gujjar, A. A., M. A. Malik. "Preparation of Instructional Material for Distance Teacher Education". Turkish Online Journal of Distance Education 8/1 (2007): 55-63. 
Gümrükçüoğlu, S., M. F. Genç. "ILiTAM Bölümü Öğrencilerinin İlâhiyat Eğitimine Bakışı Kocaeli Üniversitesi İlâhiyat Fakültesi İLiTAM Örneği". iHYA Uluslararası İslam Araştırmaları Dergisi. 6/2 (2020): 640-656.

Karasar, N. Bilimsel Araştırma Yöntemleri. Ankara: Nobel Yayınları, 2020.

Karateke, Tuncay. "ILITAM Öğrencilerinin Bu Programı Seçme Nedenleri ve Karşılaştıkları Sorunlar: Fırat Üniversitesi Örneği". Değerler Eğitimi Dergisi 18/39 (Haziran 2020): 235-262. https://doi. org/10.34234/ded.634501.

Kaymakcan, Recep, Hasan Meydan, Adnan Telli, Kübra Cevherli. “Paydaşlara Göre Illahiyat Lisans Tamamlama (ILITAM) Programının Değerlendirilmesi". Değerler Eğitimi Dergisi. 11/26 (2013): 71110.

Kaymakcan, Recep, Hasan Meydan, Adnan Telli, Kübra Cevherli. “ilahiyat Lisans Tamamlama Programının Verimliliği Üzerine Olgusal Bir Araştırma". Hitit Üniversitesi Illahiyat Fakültesi Dergisi. 13/26 (2014): 43-62.

Kılıç, Y. “Eş Zamanlı ve Eş Zamansız Uzaktan Eğitim Ortamlarındaki Çevrimiçi Etkileşimlerin Yapısal Çözümlemesi". Yayımlanmamış Yüksek Lisans Tezi, Ankara Üniversitesi Eğitim Bilimleri Enstitüsü, 2010.

Kiriş, Mustafa. Illahiyat Fakülteleri ve Diyanet Işleri Başkanlığı Ekseninde Türkiye'de Din Eğitimi. Ankara: Ilâhiyât, 2018.

Köylü, M. "Türkiye'de Yüksek Din Öğretimi: Nicelik mi Nitelik mi?". Ondokuz Mayıs Üniversitesi Illahiyat Fakültesi Dergisi, 35/35 (2013): 21-44.

Martı, Huriye. "Hadis Usulü Bilincinin Geliştirilmesi Bağlamında Illâhiyat Fakültesi Öğrencilerinin Usul Algısına Yönelik Ampirik Bir Çalışma". Necmettin Erbakan Üniversitesi Illahiyat Fakültesi Dergisi 28/28 (01 Mayıs 2009): 47-68.

Moore, M. G. "Theory of transactional distance". Theoretical principles of distance education içinde. ss. 20-35. London: Routledge, 1993.

Polat, Salahattin. "Ilahiyat Fakültelerinde Hadis Dersleri (Amaç, Muhteva ve Metot Hakkında Teklifler)". Yüksek Öğretimde Din Bilimleri Öğretimi Sempozyumu Kitabı içinde. ss. 362-370. Bu bildiri, 21-23 Ekim 1987 tarihleri arasında Samsun'da gerçekleştirilen Yüksek Öğretimde Din Bilimleri Öğretimi Sempozyumu'nda sunulmuştur. Samsun: Ondokuz Mayıs Üniversitesi Yay., 1988.

Ürkmez, Ahmed. "Sosyal Kesimler ve Sünnet Algıları Araştırması: Malatya (Hadis Alan Yorumu)”. Süleyman Demirel Üniversitesi Ilahiyat Fakültesi Dergisi 1/28 (2012): 97-128. 
